\title{
Neutralizing monoclonal antibodies present new prospects to treat SARS-CoV-2 infections
}

\author{
Rongtao Lai*, Tianhui Zhou*, Xiaogang Xiang, Jie Lu, Haiguang Xin (ه), Qing Xie (ه) \\ Department of Infectious Diseases, Ruijin Hospital Affiliated to Shanghai Jiao Tong University School of Medicine, Shanghai 200025, China \\ (C) Higher Education Press 2021
}

\begin{abstract}
The coronavirus disease 2019 (COVID-19) has caused global public health and economic crises. Thus, new therapeutic strategies and effective vaccines are urgently needed to cope with this severe pandemic. The development of a broadly neutralizing antibody against severe acute respiratory syndrome coronavirus 2 (SARS$\mathrm{CoV}-2$ ) is one of the attractive treatment strategies for COVID-19. Currently, the receptor-binding domain (RBD) of the spike (S) protein is the main target of neutralizing antibodies when SARS-CoV-2 enters human cells through an interaction between the $S$ protein and the angiotensin-converting enzyme 2 expressed on various human cells. A single monoclonal antibody $(\mathrm{mAb})$ treatment is prone to selective pressure due to increased possibility of targeted epitope mutation, leading to viral escape. In addition, the antibody-dependent enhancement effect is a potential risk of enhancing the viral infection. These risks can be reduced using multiple mAbs that target nonoverlapping epitopes. Thus, a cocktail therapy combining two or more antibodies that recognize different regions of the viral surface may be the most effective therapeutic strategy.
\end{abstract}

Keywords neutralizing antibody; antibody cocktail; SARS-CoV-2; COVID-19; therapeutic strategy

\section{Introduction}

The coronavirus disease 2019 (COVID-19) caused by severe acute respiratory syndrome coronavirus 2 (SARSCoV-2) has led to a global pandemic, severely threatening human lives and the global economy [1]. Clinical evidence-based medicine, including guidelines based on strong evidence and the results of randomized clinical trials on COVID-19 treatment, is still evolving. While several antiviral drugs have been developed [2,3], the monoclonal antibody (mAb) therapy that can neutralize SARS-CoV-2 may be an alternative, innovative, and effective method to cope with the coronavirus infection. However, selective pressure may occur during any treatment of coronavirus infection with a single $\mathrm{mAb}$ because of the likelihood of the virus undergoing mutation, thereby escaping the detection by mAbs. By developing a cocktail therapy comprising a combination of multiple mAbs that target

Received October 17, 2020; accepted February 20, 2021

Correspondence: Qing Xie, xieqingrjh@163.com;

Haiguang Xin, allanxin@hotmail.com

${ }^{*}$ Rongtao Lai and Tianhui Zhou contributed equally to this manuscript. nonoverlapping epitopes, the risk of mutational escape can be reduced, and the therapeutic efficacy may be improved.

\section{Neutralizing antibody development}

How does SARS-CoV-2 infect humans? Virus particles enter human cells through the interaction of the spike (S) protein and the angiotensin-converting enzyme 2 (ACE2) expressed on various human cells. New viral particles are prepared inside infected cells and are released outside of the cells. In the same way, these particles can infect normal cells. Thus, if the surface of the virus S protein is the key, the ACE2 is the matching lock. If the interaction of key and lock proteins is blocked, the virus cannot replicate in large numbers. Antibodies that can block this function are called neutralizing antibodies.

Neutralizing antibodies are a class of antibodies that can prevent cells from being infected by pathogens. Once this phenomenon is achieved, the disease can be controlled, and the remaining pathogens can be slowly eliminated by the body's immune system. Neutralizing antibodies can effectively target pathogens and are a key target in vaccine development. Studies have accumulated numerous data in the development of neutralizing monoclonal antibodies to 
treat Ebola virus infections, such as Mab114, REGN-EB3, and ZMapp infections [4]. Currently, neutralizing antibodies is one of the most promising therapeutic modalities among several new coronavirus drugs under development.

Antigen-enriched B cells expressing the ACE2 receptor are isolated, and antibodies with different binding sites are screened out on the basis of the cross-reaction with SARSCoV-2. The mechanism of the cocktail therapy of neutralizing antibodies for treating SARS-CoV-2 infection is shown in Fig. 1 [5-7].

Choosing a broadly neutralizing antibody against SARS-CoV-2 is a promising strategy for treating COVID-19. However, not all neutralizing antibodies are directed against the receptor-binding domain (RBD) [8]. Chi et al. [9] have identified the 4A8 antibody from convalescent patients with COVID-19, and this antibody binds to the N-terminal domain (NTD) of the SARS-CoV$2 \mathrm{~S}$ protein instead of the RBD. The identification of this antibody indicates that neutralizing antibodies act via diverse mechanisms. Thus, the NTD of the S protein may be a potential target for generating neutralizing antibodies to treat COVID-19. Pinto et al. [10] have described the S309 monoclonal antibody, which can effectively neutralize SARS-CoV-2 by binding to the RBD of the S glycoprotein. Cao et al. [11] have used the high-throughput single-cell RNA and VDJ sequencing methods to identify
SARS-CoV-2-neutralizing antibodies from the antigenenriched B cells of 60 convalescent patients and successfully identified 14 effective neutralizing antibodies, of which the BD-368-2 is the most effective. Another study has revealed that owing to its unique binding epitope, the binding of BD-368-2 to the S protein RBD is not affected by its spatial location. Irrespective of the "up" or "down" conformation of RBD, the BD-368-2 can bind to the RBD and completely block the binding of the $\mathrm{S}$ protein trimer to the ACE2 receptor [12]. In a recent study conducted before the COVID-19 pandemic, Kreer et al. [13] have performed the deep sequencing of naïve B cells from 48 healthy individuals and identified light chain and/or heavy chain precursor sequences with the SARS-CoV-2-neutralizing activity. These gene fragments encode effective neutralizing antibodies, suggesting that protective antibodies can be easily induced by vaccines.

Notably, anti-SARS-CoV-2 antibodies can exacerbate COVID-19 via a mechanism referred to as the antibodydependent enhancement (ADE) [14]. Previous vaccine studies have warned of clinical safety risks associated with ADE in humans, which may lead to the failure of vaccine trials. ADE occurs in viral infections through different mechanisms, such as increased viral infection and replication or enhanced inflammation and a pathological immune response [15]. Coronaviruses have now spread across

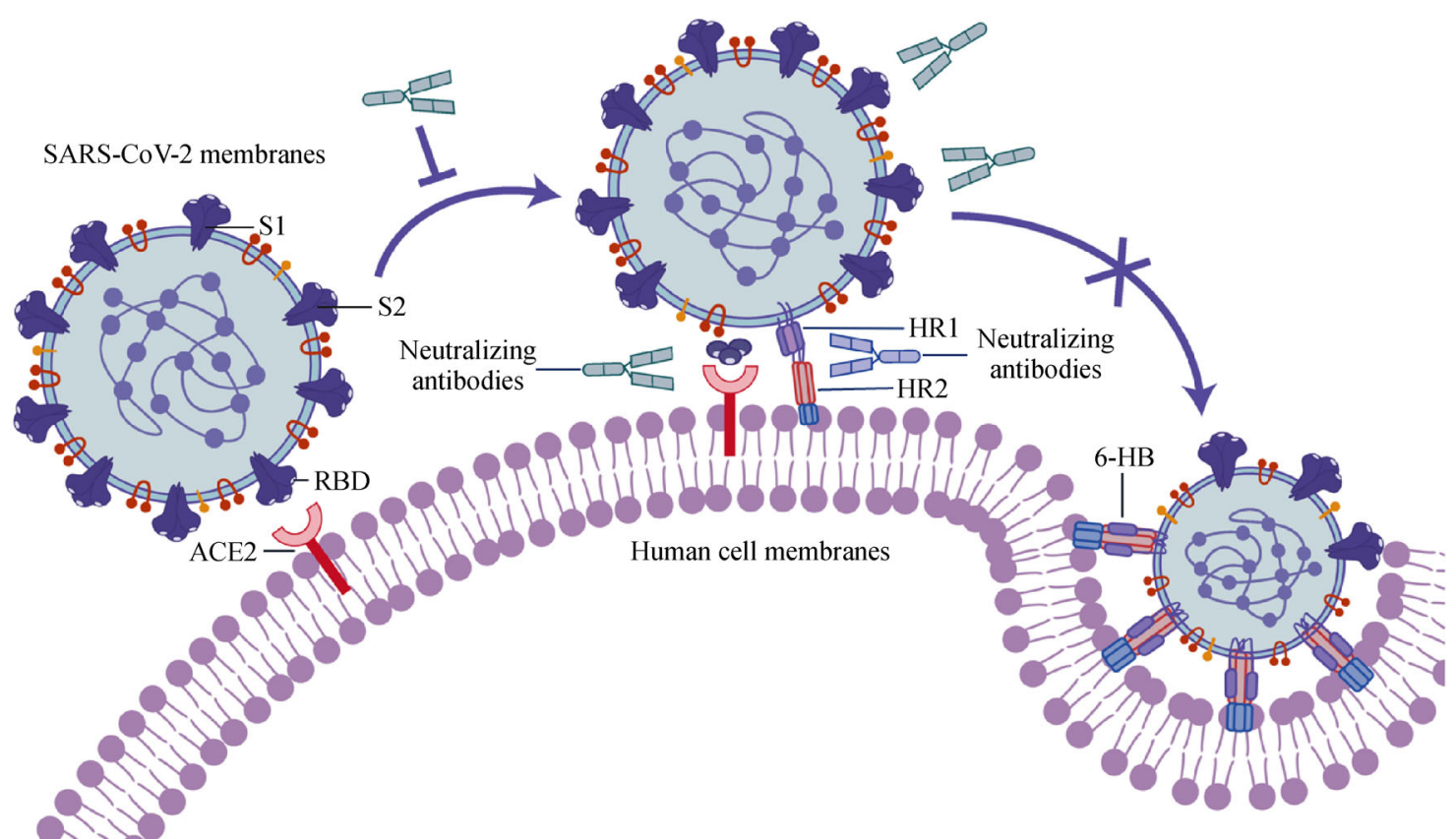

Fig. 1 Mechanism of the cocktail therapy of neutralizing antibodies for treating the severe acute respiratory syndrome coronavirus 2 (SARS-CoV-2) infection. Neutralizing antibodies (blue) target different epitopes of the S1 subunit of SARS-CoV-2, intercepting the virus from binding to ACE2 on the surface of human cells, thereby preventing the virus from entering the host cell. The S2 subunit enters the human cell membrane as the viral fusion peptide, thereby inducing a conformational change in the S2 subunit and forms a 6-HB trimer with HR1 and HR2 domains in the virus fusion stage. Neutralizing antibodies (purple) disturb the 6-HB formation by binding the HR1 domain to inhibit the fusion of SARS-CoV-2 and host cell. ACE2, angiotensin-converting enzyme 2; 6-HB, 6-helix bundle; HR1, heptad repeat 1 ; HR2, heptad repeat 2 . 
species and become highly pathogenic. Moreover, coronaviruses can rapidly spread within a population. In addition, the virus can mutate, thereby posing an enormous challenge to the development of antiviral drugs.

\section{Concept and benefits of an antibody cocktail therapy}

The concept of cocktail therapy is first used for HIV infections. By combining three or more antiviral drugs, resistance to a drug can be reduced, thereby suppressing viral replication to the maximum extent, delaying disease progression, and improving the quality of life of patients [16]. The combination therapy has been successfully used in the field of oncology aside from viral infection treatments, and several new combination therapies comprising targeted therapy drugs have achieved clinical success $[17,18]$. In addition to approved antiviral drugs, $\mathrm{mAbs}$ are the leading candidates in vaccine development due to advances in the mAb technology [19].

\section{Clinical practice with antibody cocktail therapies}

Twenty registered clinical trials on COVID-19 treatment with neutralizing antibodies are either recruiting patients or have been completed, of which eight clinical trials are phase 2, 3, and 4 trials. Table 1 summarizes the eight registered clinical trials of neutralizing mAbs with therapeutic potential against SARS-CoV-2 reported so far, and trial results will be available soon.

Recently, Jones et al. have announced that in a randomized, double-blind, placebo-controlled phase 2 clinical trial, the cocktail therapy of neutralizing antibodies LY-CoV555 and LY-CoV016 can significantly reduce viral load and disease symptoms in patients with mild and moderate COVID-19 [20]. In the high-risk subgroup of patients with age $>65$ years or BMI $>35 \mathrm{~kg} / \mathrm{m}^{2}$, the combination therapy can reduce the proportion of patients who are hospitalized or require emergency treatment from $13.5 \%$ to $0 \%$. Results show that high-risk patients with

Table 1 Eight registered clinical trials of neutralizing mAbs with therapeutic potential against SARS-CoV-2

\begin{tabular}{|c|c|c|c|c|c|}
\hline $\begin{array}{l}\text { Clinical trial } \\
\text { identifier }\end{array}$ & Study type & $\begin{array}{l}\text { Estimated } \\
\text { enrollment }\end{array}$ & Subjects & Treatment & Primary objectives \\
\hline NCT04425629 & $\begin{array}{l}\text { Randomized/ } \\
\text { double-blind study }\end{array}$ & 2104 & $\begin{array}{l}\text { Ambulatory patients with } \\
\text { COVID-19 }\end{array}$ & $\begin{array}{l}\text { Low-dose REGN10933 + } \\
\text { REGN10987, high-dose } \\
\text { REGN10933 + REGN10987 }\end{array}$ & $\begin{array}{l}\text { To evaluate the clinical efficacy } \\
\text { of REGN10933 + } \\
\text { REGN10987 compared with } \\
\text { placebo }\end{array}$ \\
\hline NCT04426695 & $\begin{array}{l}\text { Randomized/ } \\
\text { double-blind study }\end{array}$ & 2970 & $\begin{array}{l}\text { Hospitalized adult patients } \\
\text { with COVID-19 }\end{array}$ & REGN10933 + REGN10987 & $\begin{array}{l}\text { Proportion of patients with } \\
\text { treatment-emergent serious } \\
\text { adverse events }\end{array}$ \\
\hline NCT04452318 & $\begin{array}{l}\text { Randomized/ } \\
\text { double-blind study }\end{array}$ & 2000 & $\begin{array}{l}\text { Asymptomatic adults with } \\
\text { SARS-CoV-2 infection }\end{array}$ & REGN10933 + REGN10987 & $\begin{array}{l}\text { Proportion of participants who } \\
\text { have a positive SARS-CoV-2 } \\
\text { RT-qPCR and signs and symp- } \\
\text { toms of SARS-CoV-2 infection } \\
\text { during the efficacy assessment } \\
\text { period }\end{array}$ \\
\hline NCT04427501 & $\begin{array}{l}\text { Randomized/ } \\
\text { double-blind study }\end{array}$ & 800 & $\begin{array}{l}\text { Patients with mild to } \\
\text { moderate COVID-19 }\end{array}$ & $\begin{array}{l}\text { LY3819253 (LY-CoV555) or } \\
\text { LY3819253 + LY3832479 } \\
\text { (LY-CoV016) }\end{array}$ & $\begin{array}{l}\text { Change in SARS-CoV-2 viral } \\
\text { load from baseline to day } 11\end{array}$ \\
\hline NCT04545060 & $\begin{array}{l}\text { Randomized/ } \\
\text { double-blind study }\end{array}$ & 1360 & $\begin{array}{l}\text { Nonhospitalized patients } \\
\text { with COVID-19 }\end{array}$ & $\begin{array}{l}\text { Monoclonal antibody } \\
\text { VIR-7831 }\end{array}$ & $\begin{array}{l}\text { Proportion of participants who } \\
\text { have progression of COVID- } 19 \\
\text { until day } 29\end{array}$ \\
\hline NCT04390464 & $\begin{array}{l}\text { Randomized/ } \\
\text { open-label study }\end{array}$ & 1167 & $\begin{array}{l}\text { Admitted pre-ICU patients } \\
\text { with COVID-19 }\end{array}$ & $\begin{array}{l}\text { Ravulizumab (monoclonal } \\
\text { antibody that binds to the } \\
\text { terminal complement protein } \\
\text { C5) or baricitinib } \\
\text { (antirheumatic drug) }\end{array}$ & $\begin{array}{l}\text { Time to incidence of the com- } \\
\text { posite endpoint of death, } \\
\text { mechanical ventilation, ECMO, } \\
\text { cardiovascular organ support, } \\
\text { or renal failure }\end{array}$ \\
\hline NCT04634409 & $\begin{array}{l}\text { Randomized/ } \\
\text { double-blind study }\end{array}$ & 500 & $\begin{array}{l}\text { Participants with mild to } \\
\text { moderate COVID-19 }\end{array}$ & $\begin{array}{l}\text { LY3819253 (LY-CoV555) and } \\
\text { LY3832479 (LY-CoV016) }\end{array}$ & $\begin{array}{l}\text { Percentage of participants with } \\
\text { SARS-CoV-2 viral load higher } \\
\text { than } 5.27\end{array}$ \\
\hline NCT04381936 & $\begin{array}{l}\text { Randomized/ } \\
\text { open-label study }\end{array}$ & 15000 & Patients with COVID-19 & $\begin{array}{l}\text { Drug: lopinavir-ritonavir } \\
\text { Drug: corticosteroid } \\
\text { Drug: hydroxychloroquine } \\
\text { Drug: azithromycin } \\
\text { Biological: convalescent plasma } \\
\text { Drug: tocilizumab } \\
\text { Biological: immunoglobulin } \\
\text { Drug: synthetic neutralizing } \\
\text { antibodies }\end{array}$ & $\begin{array}{l}\text { All-cause mortality (within } 28 \\
\text { days after randomization) }\end{array}$ \\
\hline
\end{tabular}


COVID-19 are more likely to benefit from the cocktail therapy. Junshi Biology and the Chinese Academy of Sciences have cooperatively developed the neutralizing antibody JS016 (LY-CoV016). Eli Lilly has obtained the authorization from Junshi Biology outside Greater China. LY-CoV555 is a neutralizing antibody developed by Eli Lilly, AbCellera, and the National Institute of Allergy and Infectious Diseases. The Regeneron Pharmaceuticals has used humanized VelocImmune mice and peripheral blood from patients who have recovered from COVID-19 to isolate a single $\mathrm{B}$ cell for locating the epitope on the RBD of the $\mathrm{S}$ protein on SARS-CoV-2. Researchers have combined two SARS-CoV-2 virus monoclonal antibodies with strong neutralizing ability and do not identify overlapping epitopes in the $\mathrm{S}$ protein to reduce the risk of treatment failure due to the epitope mutation. Researchers have referred to this cocktail therapy as "REGNCOV2" (REGN10933 + REGN10987) [21]. The deep sequencing reveals that the combination of two monoclonal antibodies can overcome the limitation of a single antibody, providing the possibility of " $1+1>2$." The results of the clinical trial show that REGN-COV2 can significantly reduce the viral load in patients and shorten the time for relief from symptoms. After seven days of treatment, REGN-COV2 significantly reduces the viral load in seronegative patients [22]. Lilly and Regeneron have submitted a request for emergency use authorization for monotherapy and REGN-COV2, respectively, to the U.S. Food and Drug Administration (FDA) [20,22]. However, neither the therapeutic antibodies (i.e., LY3819253 and LY3832479) nor REGN-COV2 have been approved by the FDA, and these data are from the companies' official website. The data have neither been peer reviewed nor officially published. Therefore, rigorous, objective, detailed, and reliable data are needed to verify the clinical reliability of these therapies.

\section{Summary}

The mechanism of the SARS-CoV-2 infection is not fully understood. The development of neutralizing antibodies against SARS-CoV-2 has some challenges, such as mutations in the less conservative region of the $\mathrm{S} 1$ subunit and the induction of ADE by non-neutralizing antibodies. In addition, monoclonal antibodies may not recognize different viral strains, and mutations in the virus can lead to viral escape [23]. The use of a cocktail therapy may help identify neutralizing and non-neutralizing epitopes on the surface of the virus that interact with human cells, thereby representing a promising therapeutic strategy. Finally, because antibodies are protein drugs, their production, transportation, and storage represent significant limitations in addition to the expense involved in their production.
Thus, further research is needed before their large-scale applications.

\section{Acknowledgements}

This study was supported by the National Natural Science Foundation of China (No. 81970514), the Shanghai Municipal Key Clinical Specialty (No. shslczdzk01103), and the Shanghai Municipal Planning Commission of Science and Research Fund (No. 202040111).

\section{Compliance with ethics guidelines}

Rongtao Lai, Tianhui Zhou, Xiaogang Xiang, Jie Lu, Haiguang Xin, and Qing Xie declare that they have no conflict of interest. This manuscript does not involve a research protocol requiring approval by the relevant institutional review board or ethics committee.

\section{References}

1. Bedford J, Enria D, Giesecke J, Heymann DL, Ihekweazu C, Kobinger G, Lane HC, Memish Z, Oh MD, Sall AA, Schuchat A, Ungchusak K, Wieler LH; WHO Strategic and Technical Advisory Group for Infectious Hazards. COVID-19: towards controlling of a pandemic. Lancet 2020; 395(10229): 1015-1018

2. Ali MJ, Hanif M, Haider MA, Ahmed MU, Sundas F, Hirani A, Khan IA, Anis K, Karim AH. Treatment options for COVID-19: a review. Front Med (Lausanne) 2020; 7: 480

3. Tang W, Cao Z, Han M, Wang Z, Chen J, Sun W, Wu Y, Xiao W, Liu S, Chen E, Chen W, Wang X, Yang J, Lin J, Zhao Q, Yan Y, Xie Z, Li D, Yang Y, Liu L, Qu J, Ning G, Shi G, Xie Q. Hydroxychloroquine in patients with mainly mild to moderate coronavirus disease 2019: open label, randomised controlled trial. BMJ 2020; 369: m1849

4. Mulangu S, Dodd LE, Davey RT Jr, Tshiani Mbaya O, Proschan M, Mukadi D, Lusakibanza Manzo M, Nzolo D, Tshomba Oloma A, Ibanda A, Ali R, Coulibaly S, Levine AC, Grais R, Diaz J, Lane HC, Muyembe-Tamfum JJ; PALM Writing Group, Sivahera B, Camara M, Kojan R, Walker R, Dighero-Kemp B, Cao H, Mukumbayi P, Mbala-Kingebeni P, Ahuka S, Albert S, Bonnett T, Crozier I, Duvenhage M, Proffitt C, Teitelbaum M, Moench T, Aboulhab J, Barrett K, Cahill K, Cone K, Eckes R, Hensley L, Herpin B, Higgs E, Ledgerwood J, Pierson J, Smolskis M, Sow Y, Tierney J, Sivapalasingam S, Holman W, Gettinger N, Valllée D, Nordwall J; PALM Consortium Study Team. A randomized, controlled trial of Ebola virus disease therapeutics. N Engl J Med 2019; 381(24): 2293-2303

5. Ho M. Perspectives on the development of neutralizing antibodies against SARS-CoV-2. Antib Ther 2020; 3(2): 109-114

6. Yan R, Zhang Y, Li Y, Xia L, Guo Y, Zhou Q. Structural basis for the recognition of SARS-CoV-2 by full-length human ACE2. Science 2020; 367(6485): 1444-1448

7. Vaduganathan M, Vardeny O, Michel T, McMurray JJV, Pfeffer MA, Solomon SD. Renin-angiotensin-aldosterone system inhibitors in patients with Covid-19. N Engl J Med 2020; 382(17): 1653-1659 
8. Brouwer PJM, Caniels TG, van der Straten K, Snitselaar JL, Aldon Y, Bangaru S, Torres JL, Okba NMA, Claireaux M, Kerster G, Bentlage AEH, van Haaren MM, Guerra D, Burger JA, Schermer EE, Verheul KD, van der Velde N, van der Kooi A, van Schooten J, van Breemen MJ, Bijl TPL, Sliepen K, Aartse A, Derking R, Bontjer I, Kootstra NA, Wiersinga WJ, Vidarsson G, Haagmans BL, Ward AB, de Bree GJ, Sanders RW, van Gils MJ. Potent neutralizing antibodies from COVID-19 patients define multiple targets of vulnerability. Science 2020; 369(6504): 643-650

9. Chi X, Yan R, Zhang J, Zhang G, Zhang Y, Hao M, Zhang Z, Fan P, Dong Y, Yang Y, Chen Z, Guo Y, Zhang J, Li Y, Song X, Chen Y, Xia L, Fu L, Hou L, Xu J, Yu C, Li J, Zhou Q, Chen W. A neutralizing human antibody binds to the $\mathrm{N}$-terminal domain of the Spike protein of SARS-CoV-2. Science 2020; 369(6504): 650655

10. Pinto D, Park YJ, Beltramello M, Walls AC, Tortorici MA, Bianchi S, Jaconi S, Culap K, Zatta F, De Marco A, Peter A, Guarino B, Spreafico R, Cameroni E, Case JB, Chen RE, Havenar-Daughton C, Snell G, Telenti A, Virgin HW, Lanzavecchia A, Diamond MS, Fink K, Veesler D, Corti D. Cross-neutralization of SARS-CoV-2 by a human monoclonal SARS-CoV antibody. Nature 2020; 583(7815): 290-295

11. Cao Y, Su B, Guo X, Sun W, Deng Y, Bao L, Zhu Q, Zhang X, Zheng Y, Geng C, Chai X, He R, Li X, Lv Q, Zhu H, Deng W, Xu Y, Wang Y, Qiao L, Tan Y, Song L, Wang G, Du X, Gao N, Liu J, Xiao J, Su XD, Du Z, Feng Y, Qin C, Qin C, Jin R, Xie XS. Potent neutralizing antibodies against SARS-CoV-2 identified by highthroughput single-cell sequencing of convalescent patients' B cells. Cell 2020; 182(1): 73-84.e16

12. Du S, Cao Y, Zhu Q, Yu P, Qi F, Wang G, Du X, Bao L, Deng W, Zhu H, Liu J, Nie J, Zheng Y, Liang H, Liu R, Gong S, Xu H, Yisimayi A, Lv Q, Wang B, He R, Han Y, Zhao W, Bai Y, Qu Y, Gao X, Ji C, Wang Q, Gao N, Huang W, Wang Y, Xie XS, Su XD, Xiao J, Qin C. Structurally resolved SARS-CoV-2 antibody shows high efficacy in severely infected hamsters and provides a potent cocktail pairing strategy. Cell 2020; 183(4): 1013-1023.e13

13. Kreer C, Zehner M, Weber T, Ercanoglu MS, Gieselmann L, Rohde C, Halwe S, Korenkov M, Schommers P, Vanshylla K, Di Cristanziano V, Janicki H, Brinker R, Ashurov A, Krähling V, Kupke A, Cohen-Dvashi H, Koch M, Eckert JM, Lederer S, Pfeifer N, Wolf T, Vehreschild MJGT, Wendtner C, Diskin R, Gruell H, Becker S, Klein F. Longitudinal isolation of potent near-germline SARS-CoV-2-neutralizing antibodies from COVID-19 patients. Cell 2020; 182(4): 843-854.e12

14. Lee WS, Wheatley AK, Kent SJ, DeKosky BJ. Antibody-dependent enhancement and SARS-CoV-2 vaccines and therapies. Nat Microbiol 2020; 5(10): 1185-1191

15. Karthik K, Senthilkumar TMA, Udhayavel S, Raj GD. Role of antibody-dependent enhancement (ADE) in the virulence of SARSCoV-2 and its mitigation strategies for the development of vaccines and immunotherapies to counter COVID-19. Hum Vaccin Immun- other 2020; 16(12): 3055-3060

16. Cohen J. HIV/AIDS. Prevention cocktails: combining tools to stop HIV's spread. Science 2005; 309(5737): 1002-1005

17. Van Meir EG, Hadjipanayis CG, Norden AD, Shu HK, Wen PY, Olson JJ. Exciting new advances in neuro-oncology: the avenue to a cure for malignant glioma. CA Cancer J Clin 2010; 60(3): 166-193

18. Ledford H. Cocktails for cancer with a measure of immunotherapy. Nature 2016; 532(7598): 162-164

19. Andrews CD, Huang $\mathrm{Y}, \mathrm{Ho} \mathrm{DD}$, Liberatore RA. In vivo expressed biologics for infectious disease prophylaxis: rapid delivery of DNAbased antiviral antibodies. Emerg Microbes Infect 2020; 9(1): 15231533

20. Jones BE, Brown-Augsburger PL, Corbett KS, Westendorf K, Davies J, Cujec TP, Wiethoff CM, Blackbourne JL, Heinz BA, Foster D, Higgs RE, Balasubramaniam D, Wang L, Bidshahri R, Kraft L, Hwang Y, Žentelis S, Jepson KR, Goya R, Smith MA, Collins DW, Hinshaw SJ, Tycho SA, Pellacani D, Xiang P, Muthuraman K, Sobhanifar S, Piper MH, Triana FJ, Hendle J, Pustilnik A, Adams AC, Berens SJ, Baric RS, Martinez DR, Cross RW, Geisbert TW, Borisevich V, Abiona O, Belli HM, de Vries M, Mohamed A, Dittmann M, Samanovic M, Mulligan MJ, Goldsmith JA, Hsieh CL, Johnson NV, Wrapp D, McLellan JS, Barnhart BC, Graham BS, Mascola JR, Hansen CL, Falconer E. LY-CoV555, a rapidly isolated potent neutralizing antibody, provides protection in a non-human primate model of SARS-CoV-2 infection. bioRxiv 2020; [Preprint] doi:10.1101/2020.09.30.318972

21. Hansen J, Baum A, Pascal KE, Russo V, Giordano S, Wloga E, Fulton BO, Yan Y, Koon K, Patel K, Chung KM, Hermann A, Ullman E, Cruz J, Rafique A, Huang T, Fairhurst J, Libertiny C, Malbec M, Lee WY, Welsh R, Farr G, Pennington S, Deshpande D, Cheng J, Watty A, Bouffard P, Babb R, Levenkova N, Chen C, Zhang B, Romero Hernandez A, Saotome K, Zhou Y, Franklin M, Sivapalasingam S, Lye DC, Weston S, Logue J, Haupt R, Frieman M, Chen G, Olson W, Murphy AJ, Stahl N, Yancopoulos GD, Kyratsous CA. Studies in humanized mice and convalescent humans yield a SARS-CoV-2 antibody cocktail. Science 2020; 369(6506): 1010-1014

22. Weinreich DM, Sivapalasingam S, Norton T, Ali S, Gao H, Bhore R, Musser BJ, Soo Y, Rofail D, Im J, Perry C, Pan C, Hosain R, Mahmood A, Davis JD, Turner KC, Hooper AT, Hamilton JD, Baum A, Kyratsous CA, Kim Y, Cook A, Kampman W, Kohli A, Sachdeva Y, Graber X, Kowal B, DiCioccio T, Stahl N, Lipsich L, Braunstein N, Herman G, Yancopoulos GD; Trial Investigators. REGN-COV2, a neutralizing antibody cocktail, in outpatients with Covid-19. N Engl J Med 2021; 384(3): 238-251

23. ter Meulen J, van den Brink EN, Poon LL, Marissen WE, Leung CS, Cox F, Cheung CY, Bakker AQ, Bogaards JA, van Deventer E, Preiser W, Doerr HW, Chow VT, de Kruif J, Peiris JS, Goudsmit J. Human monoclonal antibody combination against SARS coronavirus: synergy and coverage of escape mutants. PLoS Med 2006; 3 (7): e 237 